\title{
Two New Cultures in Delaware County, Oklahoma
}

David A. Baerreis

Unknown

Follow this and additional works at: https://scholarworks.sfasu.edu/ita

Part of the American Material Culture Commons, Archaeological Anthropology Commons, Environmental Studies Commons, Other American Studies Commons, Other Arts and Humanities Commons, Other History of Art, Architecture, and Archaeology Commons, and the United States History Commons

Tell us how this article helped you.

This Article is brought to you for free and open access by the Center for Regional Heritage Research at SFA ScholarWorks. It has been accepted for inclusion in Index of Texas Archaeology: Open Access Gray Literature from the Lone Star State by an authorized editor of SFA ScholarWorks. For more information, please contact cdsscholarworks@sfasu.edu. 


\section{Two New Cultures in Delaware County, Oklahoma}

Creative Commons License

(c) (i) (8)

This work is licensed under a Creative Commons Attribution-NonCommercial 4.0 International License 


\title{
TWO NEW CULTURES IN DELAWARE COUNTY, OKLAHOMA
}

\author{
David A. Baerreis
}

The Mode site (ed. note: 34DL39) is an extensive village site on the banks of Grand River. Only a small portion of the site has been explored as yet, so the scope of our knowledge of this aspect will soon be considerably expanded.

Cultural remains were found scattered through about three feet of soil and in three cache pits which extended below this into yellowish, sandy subsoil. The pottery found in the various levels appeared to be quite homogeneous.

The paste of the pottery ranges in color from grey-black to brown, red or buff. A slip, usually red or buff, is sometimes present on the exterior or both exterior and interior. The temper is predominantly shell, occasionally grit or pulverized pottery being added. In all cases shell was the most abundant tempering material. The texture is variable, being occasionally soft and crumbly but normally hard and firm. The variation in texture is possibly due to a leaching action since in a large percentage of the pottery the shell temper had dissolved leaving shallow pits. When a sherd is broken the original shell temper can still be seen in the interior. Medium sized temper $(2-4 \mathrm{~mm})$ is found in $66 \%$ of the pottery. The thickness of the sherds is predominantly thin and medium, with $53 \%$ thin (under $3 \mathrm{~mm}$ ) and $42 \%$ medium (3-6 mm).

Several types of vessels can be recognized from the rim sections. A common form was the wide-mouthed bowl. The most abundant was the olla, the rim usually being very short and ranging from straight to recurved and flaring. Basal sherds are all flat and round in outline.

Only $7 \%$ or 50 out of the total number of 726 sherds bore a decoration (ed. note: see Figure 1). The body decorative elements consist of broad trailed lines, fine trailed line, incised lines and a wedge-shaped punctate element formed by pressing a small cylinder, such as a reed, held at an acute angle into the soft clay. The broad

\footnotetext{
3 Condensed from reports of the Delaware County section of the WPA Archaeological Project under the direction of Dr. Forrest Clements of the University of Oklahoma. [ed. note: WPA reports are filed at the Oklahoma Museum of Natural History, The University of Oklahoma. In addition, several boxes of WPA records are curated in the Western History Collection archives, The University of Oklahoma.]
} 


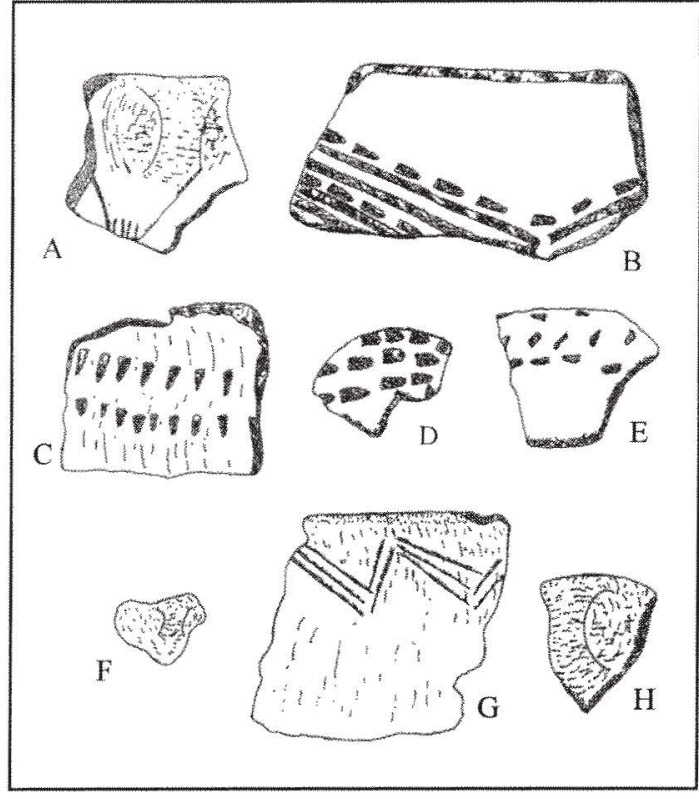

Figure 1. Sherds from the Mode site: a) strap handle, fine trailed decoration; b) punctate lip, punctate and broad trailed decoration on body; $c, d, e)$ punctate decoration on body sherds; f) small decorative handle; $g$ ) incised decoration; $h$ ) strap handle.

trailed lines occur bordered by punctate elements or in a pattern where two trailed lines alternate with punctate elements. The punctate elements occur alone in horizontal rows of vertically placed elements, rows of horizontal elements and a combination of horizontal and vertical elements. The incised lines are found in diagonally opposed groups of two or three lines forming a zig-zag pattern, and in alternate areas of vertical and diagonal lines. The fine trailed lines are found in a single zigzag line with short trailed lines at the lower angle.

Ten of the 18 decorated rim sherds found have a decoration on the lip. Seven are the ordinary wedge-shaped punctate type already described placed parallel to the curve of the rim. Two were set diagonally to the rim and one sherd had a diagonally notched lip. Three handles bore punctate impressions upon the handle itself.

Only nine projectile points were found. Of these, four were large stemmed points. The remainder were small triangular points. The large stemmed points were all found close to the surface, only one being found below the plow line. The small triangular points were considerably deeper, two being found in caches. They appear to be definitely tied in with the culture, whereas the connection of the large type is problematical.

End scrapers were present both in the regular strata and in caches. They varied in shape but normally taper in the back. Some were carefully retouched on all edges, whereas others were retouched only on the end and had a slight dorsal keel. Flake knives and side scrapers were common. One flake knife has its opposing edges beveled on opposite sides of the knife.

Stone drills are long and slender with the base carefully finished. Both a round base and a convex base were found. Three chipped axes were found well below the plow line. The axes are double-bitted, contracting at the center of the implement, with one end the primary cutting edge. A piece of chert, $19.6 \mathrm{~cm}$ long and triangular in cross-section, has been worked into what would serve admirably as a fist axe. The blunt end has been pecked until no sharp edges were left on the chert while 
the pointed edge is sharp and unworn.

One polished celt of a light, porous limestone was found. Sandstone abrading stones were abundant. A few of these are rectangular and bear wide, straight grooves that could be used as shaft polishers. The remainder are irregular in shape and have tapering grooves probably used for sharpening bone implements. Rounded pecking stones were numerous. Oval shaped manos of sandstone and limestone, carefully worked into shape, were found. More abundant, however, were irregular muller stones with one surface showing its use in grinding.

One rib was found having a narrow edge carefully polished and bearing a series of notches. A blunt antler tip, possibly used as a flaking tool, was also found.

The decorative complex bears a decided resemblance to the Oneota Aspect. Additional excavation is necessary to increase the number of decorative patterns, and to confirm or deny the inclusion of the various implements mentioned in the cultural pattern. The assigning of the chipped axe, which is so abundant in surface material of this region, to a definite culture seems important.

Our second new culture was found at the Cooper site at the mouth of Honey Creek (ed. note: 34DL33 and 34DL49). The material here was also found scattered through the top soil.

The pottery complex is entirely different. The paste is normally grey or black. A soft slip, red or buff in color, almost approach-

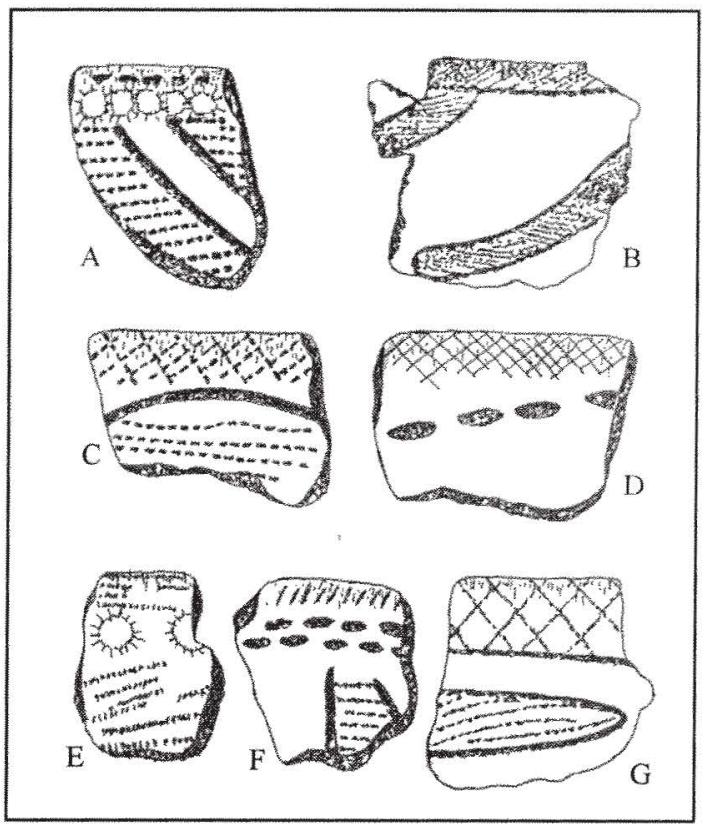

Figure 2. Sherds from the Cooper site: a) punctate decoration near lip, row of medium nodes pressed from the interior on rim, bands of toothed comb impressions bordered by trailed line on body; b) diagonal rouletting on rim bordered by trailed line on body; $c, g)$ cross-hatching of toothed comb impressions on rim, rouletting bordered by trailed line on body; d) incised crosshatching on rim, large ovoid punctate impressions on body; e) horizontal rouletting on upper part of rim, row of large nodes pressed from the interior below, scattered rouletting on body; f) small diagonal incisions on rim near lip, two horizontal rows of oval punctate impressions on lower part of rim, toothed comb impressions bordered by trailed line on body.

ing a wash, is usually present. The temper is entirely grit, either crushed flint or limestone.

Decorative elements consist of broad trailed lines, rouletting or dentate stamped impressions, large and small nodes formed by punching from the interior of the vessel, round punctate impressions and, 
rarely, impressions of a cord-wrapped stick (ed. note: see Figure 2). These elements are arranged in definite patterns on the vessels. A narrow band of decoration consisting of diagonal rouletting or incising, or cross-hatching of rouletting or incising, bordered on the lower edge by a broad trailed line, is usually present on the rim. Below this is often found a single and sometimes a double row of large or small nodes. Occasionally depressions take the place of the nodes. The body of the vessels is normally decorated by rouletting or short trailed lines, bordered by a shallow, broad trailed line, arranged in varying patterns.

The olla is present here also, but no flat bases were found. Both straight and recurved rims are present. A unique feature is a rim type which expands abruptly in thickness as it approaches a flat lip.
Projectile points are almost exclusively the large stemmed types, usually with a flaring heft. End scrapers are very abundant, both with a high, rough dorsal keel and flat, carefully chipped types. Bunts are numerous. Large drills and projectile points reworked into drills appear to be characteristic of the culture. Oval manos and metates were found. One cupstone was present. A small adze-like implement of polished stone was found.

The decorative pattern is similar to some of the Hopewell material. The Renner Site near Kansas City excavated recently by Waldo R. Wedel appears to contain a number of similar decorative patterns. Excavation has not been completed at this site and it is possible we may be able to obtain some house patterns from post molds partially uncovered recently. 


\title{
Update on Publications About These Delaware County Sites
}

\author{
Lois E. Albert
}

The Cooper sites, considered a Hopewellian incursion into northeastern Oklahoma, were presented briefly in an overview of Oklahoma archeology (Bell and Baerreis 1951). The sites were located near the mouth of Honey Creek, at its junction with Grand River. They are now innundated by Grand Lake. Baerreis (1953) studied the pottery further, breaking it down into types. A more detailed study of the pottery, as well as a partial one of the lithics, was done by Purrington (1970) as his dissertation research at the University of Wisconsin. These studies were summarized, with some added information, by Vehik (1984) in a discussion of Oklahoma's Woodland period occupations.

Freeman (1962) used Baerreis' analyses and discussion of the Mode site presented in this paper and in WPA reports, combined with those of other sites in the area, in a summary of the Neosho focus. A more complete discussion was presented in her dissertation (1959). The Mode site sherds were used in a comparison of Woodward Plain and Neosho Punctate by Freeman and Buck (1960). Wyckoff (1971) also mentions the Mode site in a synthesis of information about the Caddoan area, and in his dissertation (1980).

Rogers (1978) summarized the Oklahoma WPA documentary materials on file at the Stovall Museum (now Oklahoma Museum of Natural History, The University of Oklahoma). Both the Mode site and Cooper sites are represented.

\section{Later References for the Mode and Cooper Sites}

Baerreis, David A.

1939 A Hopewell Site in Northeastern

Oklahoma. Society for American Archaeology Notebook 1:72-78.

1940 The Neosho Focus. Society for American Archaeology Notebook 1:108-109.

1953 Woodland Pottery of Northeastern Oklahoma. In: Prehistoric Pottery of the Eastern United States. Museum of
Anthropology, University of Michigan, Ann Arbor.

Bell, Robert E., and David A. Baerreis

1951 A Survey of Oklahoma Archaeology. Bulletin of the Texas Archeological and Paleontological Society 22:7-100.

Freeman, Joan E. 1959 The Neosho Focus, A Late Prehistoric Culture in Northeastern 
Oklahoma. Ph.D. dissertation, Department of Anthropology, University of Wisconsin, Madison.

1962 The Neosho Focus, a Late Prehistoric Culture in Northeastern Oklahoma. Oklahoma Anthropological Society Bulletin 10:1-25.

Freeman, Joan E., and A. Dewey Buck, Jr. 1960 Woodward Plain and Neosho Punctate, Two Shell Tempered Pottery Types of Northeastern Oklahoma. Oklahoma Anthropological Society Bulletin 8:3-16.

Purrington, Burton L.

1970 The Prehistory of Delaware County, Oklahoma: Cultural Continuity and Change on the Western Ozark Periphery. Ph.D. dissertation, Department of Anthropology, University of Wisconsin, Madison.
Rogers, J. Daniel

1978 Federally Sponsored Archaeological Work in Oklahoma Before World War II. Paper presented for Anthropology 4893 (Oklahoma Archaeology, taught by Robert E. Bell), University of Oklahoma, December 12, 1978.

Vehik, Susan C.

1984 The Woodland Occupations. In: Prehistory of Oklahoma, edited by Robert E. Bell, pp. 175-197. Academic Press, Orlando.

Wyckoff, Don G.

1971 The Caddoan Cultural Area: An Archaeological Perspective. Oklahoma Archeological Survey, The University of Oklahoma, Norman.

1980 Caddoan Adaptive Strategies in the Arkansas Basin, Eastern Oklahoma. $\mathrm{Ph} . \mathrm{D}$. dissertation, Department of Anthropology, Washington State University, Pullman. 